\title{
Assessing Student Performance and Perceptions in Lecture Capture vs. Face-to-Face Course Delivery
}

\author{
Patricia Euzent, Thomas Martin, \\ Patrick Moskal, and Patsy Moskal \\ University of Central Florida, Orlando, FL, USA
}

\author{
Patricia.Euzent@bus.ucf.edu, Thomas.Martin@bus.ucf.edu \\ Patrick.Moskal@bus.ucf.edu, Patsy.Moskal@ucf.edu
}

\section{Executive Summary}

Public universities are currently facing a challenge in determining how to deliver quality instruction in the face of severe fiscal constraints. With recent technological advances, courses streamed over the Internet (i.e., lecture capture) are now becoming common. However, little research has been published that specifically examines student performance or perceptions of lecture capture courses.

This study examined student performance, student satisfaction, and student evaluation of instruction in two large $(\mathrm{N}>300)$ introductory Economics course sections. One section employed traditional face-to-face instruction, while the other employed lecture capture (LC). In this case, lecture capture refers to storing videos of actual course lectures on the college's computer server and making them available to students via the course website. Students may view these videos at their convenience, as often as they wish. The instructional methods, assignments, exams, and instructor were the same for each section over two consecutive semesters. At the end of each semester, participating students were asked to complete an online course satisfaction survey. Standard university course evaluations were also compared to examine instructor ratings in the two course delivery conditions.

The results showed no significant differences in student performance across the two delivery formats. Results did show a higher withdrawal rate in the LC sections compared to the face-toface sections (5.1\% to $1.9 \%)$. Student perceptions of LC were quite positive. Students perceived that they had more control over their learning than in a traditional face-to-face course, and more students believed that LC enhanced their performance, compared to those who thought that it did not. Eighty percent indicated that the LC course was as good as or better than a traditional large lecture course taught face-to-face, and $73 \%$ reported that they would choose to take another LC

Material published as part of this publication, either on-line or in print, is copyrighted by the Informing Science Institute. Permission to make digital or paper copy of part or all of these works for personal or classroom use is granted without fee provided that the copies are not made or distributed for profit or commercial advantage AND that copies 1) bear this notice in full and 2) give the full citation on the first page. It is permissible to abstract these works so long as credit is given. To copy in all other cases or to republish or to post on a server or to redistribute to lists requires specific permission and payment of a fee. Contact Publisher@InformingScience.org to request redistribution permission. course. The flexibility and convenience of LC were what students liked the most. Finally, students in the LC format actually gave the instructor slightly higher ratings than those in the face-toface sections, even with all readings, assignments, and exams being the same.

This research showed that instruction employing lecture capture resulted in comparable student performance and student satisfaction, relative to face-to- 
face instruction without lecture capture. The results confirm the viability of this course delivery modality when fiscal limitations are a factor and to improve course access for students. However, based on the observed withdrawal rates and previous research on distance learning, it appears that lecture capture courses may require more self-discipline because students must complete coursework on their own, and it is likely that freshmen and sophomores, who are less familiar with college, may find this medium more difficult.

Keywords: Lecture capture instruction, video-streaming, online learning, student performance, student perceptions

\section{Introduction}

Public four-year colleges are facing fiscal constraints not seen in years as a result of declining state tax revenues and declining funding to state university systems. For large and growing institutions, such as the University of Central Florida (UCF) with over 58,000 students, high enrollment has led to ever-larger class sizes. Combined with hiring restrictions, this environment has brought to the forefront the challenge of how best to deliver quality instruction to our students in the face of the financial burdens placed on a state-funded university.

Fortunately, this challenging fiscal position has come at a time of rapid improvements in technology, making possible the introduction of technology-based platforms for large class-size instruction. The use of video-streaming or lecture capture (LC) instruction offers a cost-effective method for dealing with current fiscal constraints and large class sizes. In addition to taking advantage of economies of scale in the provision of course instruction, LC also gives students more flexibility in the timing of when to receive the instruction, and it provides them the opportunity to repeat all or part of the lectures to clear up any points they may find confusing. This flexibility can be critical for the success of students, especially those who have jobs or a family.

Given the fiscal constraints on one hand, and the affordance of LC technology on the other, the question arises as to how this technology-based instruction affects the quality and the effectiveness of the service being provided. This paper addresses this question of whether technologybased LC instruction is as effective in transferring knowledge to students as the traditional faceto-face delivery of large introductory classes. That is, do students in LC course delivery perform as well as students in traditional face-to-face courses?

\section{Previous Evidence}

With many universities introducing LC delivery, there is growing research on the effectiveness of this method of instruction, although such reported research work is still sparse. The broader research literature on distance learning over the years has typically found no significant differences in student performance for the various instructional delivery modalities used. Figlio, Rush, and Yin (2010) provide a useful summary of research results on this question up to this point; none of the studies surveyed by Figlio et al. (2010) included randomly-assigned students taking a fullterm course, with live versus on-line instruction, in settings that could be directly compared (such as similar instructional materials and delivered by the same instructor). They conclude that "the relative benefits of live versus online education is therefore tenuous at best" (footnote, p. 4). Most research on distance learning or online learning was at best "quasi-experimental" - with attempts at controlling variables in a cross-sectional setting. Recent studies have generally found no significant differences in student performance between online and face-to-face courses (e.g., Arbaugh, Godfrey, Johnson, Pollack, Niendorf, \& Wresch, 2009; Gratton-Lavoie and Stanley, 2009; McFarland \& Hamilton, 2005; Means, Toyama, Murphy, Bakia, \& Jones, 2009; Russell, 2006; Sitzmann, Kraiger, Stewart, \& Wisher, 2006). Arbaugh et al. (2009) observed that performance 
differences appear to be decreasing between online and face-to-face courses as instructors and students become more familiar and comfortable with the online delivery technologies.

Sitzmann et al. (2006) did find support for online course instruction when unique or multiple learning approaches were employed, and especially when the courses were long, giving students enough time to adapt to the online technologies. Students also performed better when they had more control over their learning, including opportunities to practice, and when they received relevant feedback. However, their overall conclusions supported Clark $(1983,1994)$, who found that the type of delivery technologies used were not as important to learning as the instructional design and student characteristics. He has criticized media effectiveness research for the lack of good experimental design, and for the failure to isolate learning factors that are unique to a single medium. Also, some researchers have argued that although it is hard to isolate specific instructional attributes that affect learning, delivery approaches that possess multiple instructional attributes can contribute positively to learning (e.g., Kozma, 1994).

Although student performance in online courses has generally been found to be equivalent to face-to-face instruction, Navarro (2000) and McLaren (2004) found higher withdrawal rates in online courses. McLaren's (2004) results showed that many more students dropped out of the online course sections, but for those that completed the courses, the grades were similar between the two groups.

However, there is little research to date that has been published which specifically examines student performance and perceptions of courses that specifically employ lecture capture (LC) course delivery using video streaming technologies. In Allen, Mabry, Mattrey, Bourhis, Titsworth, and Burrell's (2004) review of communications technologies (of which video streaming was included), they found that these technologies may improve student learning. Other research has shown that using communications technologies and multimedia increased students' attention, attitudes, and interest in their courses (e.g. Lehman and Brichner, 1996; Sanders \& Morrison-Shetlar, 2001; Wise \& Groom 1996).

Cascaval, Fogler, Abrams, and Durham (2008) found that video lectures appear to help student performance because the videos can be viewed repeatedly, which helps to explain instructional content that students may have had trouble understanding the first time. Craig, Gregory, El Haggan, Braha, and Brittan-Powell (2009) found that student performance and retention also improved with lecture capture-enhanced courses compared to face-to-face alone. Dey, Burn, and Gerdes (2009) examined student performance and perceptions in live vs. online video lectures in an undergraduate physics course designed for non-majors. They found that students in the online conditions produced scores that were significantly higher than the live group on a transfer-ofknowledge question provided at the end of the session.

\section{Focus of the Present Research}

Our research study examined students' performance, perceptions, and withdrawal rates in two sections of an undergraduate Principles of Macroeconomics course, collected over two semesters. In each of the semesters, one course section (i.e., one group of students) was taught in a traditional, face-to-face setting, while the other section employed lecture capture with recorded lectures available to students over the Internet using video streaming. Students in both sections were also asked a number of questions concerning their perceptions of their learning experience, and LC students were also asked questions about the technical aspects of the lecture capture system and video display. A summary of the pertinent $\mathrm{LC}$ related questions and student responses are provided in Table 1. Finally, we were curious about overall student ratings of the instructor in these two delivery modalities, since these ratings were readily available. 
Table 1. Summary of student perceptions of important lecture capture attributes.

\begin{tabular}{|c|c|}
\hline Question & Response Percent (Frequency) \\
\hline $\begin{array}{l}\text { What was the primary location that you watched } \\
\text { videos? }(\mathrm{N}=673)\end{array}$ & $\begin{array}{l}\text { At home/apartment/dorm: } 85.0(572) \\
\text { At on campus location with Internet access: } 6.6(44) \\
\text { At job: } 1.3(9) \\
\text { Other: } 7.1(48)\end{array}$ \\
\hline $\begin{array}{l}\text { Did you watch videos in the same week as the lec- } \\
\text { ture? }(\mathrm{N}=674)\end{array}$ & $\begin{array}{l}\text { Always: } 17.7(119) \\
\text { Most of the time: } 33.5(226) \\
\text { Sometimes: } 19.9(134) \\
\text { Rarely: } 15.1(102) \\
\text { Never: } 13.8(93)\end{array}$ \\
\hline $\begin{array}{l}\text { Did you watch videos for the first time close to } \\
\text { exams? }(\mathrm{N}=674)\end{array}$ & $\begin{array}{l}\text { Always: } 2.8(19) \\
\text { Most of the time: } 12.3(83) \\
\text { Sometimes: } 25.1(169) \\
\text { Rarely: } 25.4(171) \\
\text { Never: } 34.4(232\end{array}$ \\
\hline $\begin{array}{l}\text { On average, how many times did you watch each } \\
\text { video? }(\mathrm{N}=671)\end{array}$ & $\begin{array}{l}\text { Rarely or never watched the videos: } 29.5 \text { (119) } \\
\text { Usually watched each video lecture } 1 \text { time: } 65.0(436) \\
\text { Tried to watch each video lecture } 2 \text { times: } 4.6(31) \\
\text { Tried to watch each video lecture } 3 \text { times: } 0.9(6)\end{array}$ \\
\hline $\begin{array}{l}\text { Do you feel like you have more control over your } \\
\text { learning in lecture capture courses compared to a } \\
\text { similar course taught face-to-face? }(\mathrm{N}=643)\end{array}$ & $\begin{array}{l}\text { Definitely Yes: } 38.6(248) \\
\text { Probably Yes: } 33.6(216) \\
\text { Not Sure: } 10.9(70) \\
\text { Probably Not: } 10.9(70) \\
\text { Definitely Not: } 6.1(39)\end{array}$ \\
\hline $\begin{array}{l}\text { Do you feel like lecture capture enhanced your } \\
\text { interest compared to a similar course taught face- } \\
\text { to-face? }(\mathrm{N}=643)\end{array}$ & $\begin{array}{l}\text { Definitely Yes: } 13.1(84) \\
\text { Probably Yes: } 25.0(161) \\
\text { Not Sure: } 21.0(135) \\
\text { Probably Not: } 27.4(176) \\
\text { Definitely Not: } 13.5(87)\end{array}$ \\
\hline $\begin{array}{l}\text { Do you feel like lecture capture enhanced your } \\
\text { performance compared to a similar course taught } \\
\text { face-to-face? }(\mathrm{N}=642)\end{array}$ & $\begin{array}{l}\text { Definitely Yes: } 16.2(104) \\
\text { Probably Yes: } 27.1(174) \\
\text { Not Sure: } 29.0(186) \\
\text { Probably Not: } 20.2(130) \\
\text { Definitely Not: } 7.5(48)\end{array}$ \\
\hline $\begin{array}{l}\text { Please enter your overall rating of this course } \\
\text { compared to a similar course taught face-to-face. } \\
(\mathrm{N}=642)\end{array}$ & $\begin{array}{l}\text { Much Better: } 19.2(123) \\
\text { Somewhat Better: } 26.9(173) \\
\text { About The Same: } 34.9(224) \\
\text { Somewhat Worse: } 15.1(97) \\
\text { Much Worse: } 3.9(25)\end{array}$ \\
\hline
\end{tabular}


If you have the opportunity, will you take another course that uses lecture capture? (Choices: definitely yes, probably yes, not sure, probably not, definitely not)
Definitely Yes: 38.9 (250)

Probably Yes: 34.4 (221)

Not Sure: $12.4(80)$

Probably Not: 10.3 (66)

Definitely Not: 4.0 (26)

\section{Methodology}

As mentioned in the preceding paragraph, one course section was taught in a traditional, face-toface setting, while the other section employed lecture capture. Both sections were taught over two consecutive semesters (Fall 2009 and Spring 2010). Thus, the same instructor (the first author) taught all four course sections (one face-to-face section and one LC section each semester). The same course materials, problem sets, and exams were used in each of the four sections.

\section{Lecture Capture Course Aspects}

Lecture capture courses were taught in a 280 -seat multi-media classroom. The lectures were streamed almost immediately (there was approximately a 30 second delay). Thus, students could watch the lecture nearly live on their computers, if they wished. The LC section enrollment was 565 and 647 students, respectively, for the two semesters. These students were given the option to attend the live origination section on a first-come, first-served basis, but only about $10 \%$ of students regularly attended.

The lectures were recorded on video and placed on the course website, which students may go to at their convenience. They had unlimited viewing opportunities during the semester. The videos have standard controls, such as pause, replay, and fast forward, as well as varied playback speeds, and can be downloaded to portable devices such as MP3 players.

Student enrollment in the face-to-face course sections was 377 and 318, respectively, for the two semesters. These students did not have access to the videos through their course, although it is possible that some may have gained access through friends who may have taken the LC sections. There was no way to measure this possibility, but we think the number is small.

During registration, students could choose between the LC course section and the face-to-face delivery format, but there was no random assignment. All sections met three hours per week. The LC sections employed a live origination session, with fresh lectures given each semester. LC students could opt to attend these sessions and/or they could watch the videos from wherever they had an Internet connection and watch multiple times, if desired. The lectures that were recorded and made available to students via the Internet were the actual lectures that the instructor gave in the live 280-seat classroom. Nothing was added or changed to the recorded lectures.

Identical instructional methods, exams, homework, and course policies were used in both delivery formats. Classes consisted of a combination of PowerPoint lectures and "chalk and talk." Four multiple-choice exams, given on the main campus in a testing lab, comprised $75 \%$ of the final grade. This was the only time that an LC student was required to come to campus for the course. The other $25 \%$ grade component came from Aplia, an online homework program.

\section{Equipment}

The multimedia recording/lecture capture classroom employed three cameras, including two broadcast quality television cameras that were used to record the lecture, whiteboard, etc. The third was a standard document camera. A portable microphone system that allows up to eight individuals to speak at the same time was used to capture audio throughout the classroom, when students attending the live lecture responded to the instructor or asked questions. 
The video feed was sent to the production booth at the back of the classroom, where the signals were split and directed to various workstations for recording, editing, back-up, and delivery. One version of the recording was converted and edited to be placed in the on-demand section of the college's media server, where students could access it at their convenience.

\section{Student Characteristics}

Student characteristics are provided in Table 2. The mean age of the students, averaged over both semesters was 20.5 years for the LC group and 19.5 for the face-to-face group. Thus, the LC students are, on average, slightly older than the face-to-face students. Interestingly, the gender of the face-to-face sections was split 50-50 females to males, while the LC sections were $56 \%$ female. The LC students in this course also tend to have more juniors and seniors than the face-to-face sections. However, in all sections, at least $65 \%$ of the students consisted of freshmen and sophomores.

Table 2. Summary of the student demographic variables. Means are provided for the numeric variables (italics), while percentages are provided for the category variables.

\begin{tabular}{|c|c|c|c|}
\hline $\begin{array}{c}\text { Demographic } \\
\text { Variable }\end{array}$ & Face-To-Face (N) & Lecture Capture (N) & Difference \\
\hline High School GPA & $3.65(469)$ & $3.65(585)$ & 0.00 \\
\hline University $G P A^{*}$ & $3.11(498)$ & $3.04(670)$ & 0.07 \\
\hline Total SAT Score & $1112.04(452)$ & $1120.23(576)$ & -8.19 \\
\hline Total ACT Score & $23.54(351)$ & $23.67(417)$ & -0.13 \\
\hline Age & $19.47(500)$ & $20.53(673)$ & -1.06 \\
\hline $\begin{array}{l}\text { Academic } \\
\text { Standing }\end{array}$ & $\begin{array}{l}\text { Freshman: } 43.1(217) \\
\text { Sophomore: } 36.4(183) \\
\text { Junior: } 16.1(81) \\
\text { Senior: } 3.6(18)\end{array}$ & $\begin{array}{l}\text { Freshman: } 30.7(207) \\
\text { Sophomore: } 34.7(234) \\
\text { Junior: } 25.8(174) \\
\text { Senior: } 7.6(51)\end{array}$ & $\begin{array}{c}12.4 \\
1.7 \\
-9.7 \\
-4.0\end{array}$ \\
\hline Gender ${ }^{*}$ & $\begin{array}{l}\text { Female: } 49.7(250) \\
\text { Male: } 50.3(253)\end{array}$ & $\begin{array}{l}\text { Female: } 56.4(380) \\
\text { Male: } 43.6(294)\end{array}$ & $\begin{array}{l}-6.7 \\
6.7 \\
\end{array}$ \\
\hline Employment $^{* *}$ & $\begin{array}{l}\text { Employed full-time: } 3.8 \\
\text { (19) } \\
\text { Employed part-time: } 32.0 \\
\text { (161) } \\
\text { Not employed: } 64.2 \text { (323) }\end{array}$ & $\begin{array}{l}\text { Employed full-time: } 11.8 \\
\text { (79) } \\
\text { Employed part-time: } 41.1 \\
\text { (276) } \\
\text { Not employed: } 47.2 \text { (317) }\end{array}$ & $\begin{array}{l}-8.0 \\
-9.1 \\
17.0\end{array}$ \\
\hline Ethnicity & $\begin{array}{l}\text { Asian: } 7.4 \text { (37) } \\
\text { Black/African Am: } 11.2 \\
\text { (56) } \\
\text { Hispanic/Latino: } 13.3(67) \\
\text { White: } 68.1(342) 13(502)\end{array}$ & $\begin{array}{l}\text { Asian: } 6.7 \text { (43) } \\
\text { Black/African Am: } 9.2 \\
\text { (59) } \\
\text { Hispanic/Latino: } 15.2 \\
\text { (98) } \\
\text { White: } 68.9(444)\end{array}$ & $\begin{array}{r}0.7 \\
2.0 \\
-1.9 \\
-0.8\end{array}$ \\
\hline
\end{tabular}

Quantitative variables were analyzed with analysis of variance tests, while nominal variables were analyzed with chi-square tests $\left({ }^{*} \mathrm{p}<.05,{ }^{* *} \mathrm{p}<.001\right)$. 
Many of our students were employed either full or part time, although a higher percentage of the LC students were employed ( $53 \%$ LC to $36 \%$ face-to-face). Moreover, three times as many LC students $(12 \%)$ were employed full-time compared to face-to-face students $(4 \%)$. These demographic results tend to support earlier research on online learning in which those students tend to be older, employed, and may have more females.

We could not randomly assign students into the two course delivery formats, because we would have had to change the university's course registration process, the course catalog, etc. However, demographic performance related variables indicate that the two groups of students were quite similar (Table 2). There were no significant differences in high school GPA, total SAT score, and total ACT score between the students in the two delivery conditions. There was a statistically significant difference in university GPA, with the face-to-face group GPA being only slightly higher (3.11 to 3.04). These results are also are quite consistent with those found by Figlio et al. (2010). Thus, we are confident that the two groups are close enough academically to compare their academic performance in these two delivery formats.

\section{Results}

\section{Student Performance}

Student performance, instructor evaluations, and student perceptions data were collected during the fall 2009 and spring 2010 semesters. Only those students who completed the survey, giving their consent to participate in the study, were included in the analyses. The results obtained generally support the bulk of previous literature. There was no significant difference in the final course grade between LC and the traditional face-to-face course delivery. The same result was found on the final exam performance across the two delivery modes (see Table 3). A multivariate analysis of variance with final exam and course grade as dependent measures, and delivery format as the between groups variable revealed no significant main effects or interactions.

Table 3. Summary of student performance data across semesters and delivery modalities.

\begin{tabular}{|l|l|c|c|c|c|}
\hline Semester & Delivery Mode & $\begin{array}{c}\text { Final Exam } \\
\text { Mean (Std. } \\
\text { Dev.) }\end{array}$ & $\begin{array}{c}\text { Sample } \\
\text { Size }\end{array}$ & $\begin{array}{c}\text { Course Grade } \\
\text { Point Avg. } \\
\text { Mean (Std. Dev.) }\end{array}$ & $\begin{array}{c}\text { Sample } \\
\text { Size }\end{array}$ \\
\hline Fall 2009 & Face-to-Face & $74.6(11.0)$ & 251 & $2.82(0.96)$ & 253 \\
\hline & $\begin{array}{l}\text { Lecture Cap- } \\
\text { ture }\end{array}$ & $74.3(11.6)$ & 272 & $2.77(1.03)$ & 278 \\
\hline Spring 2010 & Face-to-Face & $74.4(11.4)$ & 250 & $2.86(0.91)$ & 250 \\
\hline & $\begin{array}{l}\text { Lecture Cap- } \\
\text { ture }\end{array}$ & $73.9(11.0)$ & 392 & $2.90(0.93)$ & 396 \\
\hline Combined & Face-to-Face & $74.5(11.2)$ & 501 & $2.84(0.93)$ & 503 \\
\hline & $\begin{array}{l}\text { Lecture Cap- } \\
\text { ture }\end{array}$ & $74.1(11.2)$ & 664 & $2.85(0.97)$ & 674 \\
\hline
\end{tabular}

Students who withdrew from the course were also identified, excluding those who withdrew for medical reasons. LC courses may be more challenging for students who choose not to attend the face-to-face section because students have to be motivated and disciplined to view the videos and 
complete the assignments on their own time. It should be noted that the Aplia online homework assignments were required by students in both delivery conditions, to be completed on their own time, and each assignment had a specific due date. Thus, examining course withdrawal rates was also considered to be very important. If a large percentage of students withdrew from the lecture capture section compared to those in the face-to-face section, then this would indicate a problem with lecture capture that may not be reflected if only the results of students who completed the course were examined (e.g., McLaren, 2004; Navarro, 2000). Our results show that combined over the two semesters 13 of 695 (1.9\%) face-to-face students withdrew from the course, and 62 of $1,212(5.1 \%)$ lecture capture students withdrew. Thus, our results show a higher withdrawal rate in the LC course sections compared to the face-to-face sections, which is consistent with the findings of Navarro (2000) and McLaren (2004). LC courses require more discipline because students must watch the lectures, attend to the instructional materials, and complete coursework on their own time, and it is likely that freshmen and sophomores, in particular, may find this medium more difficult. In our case, with most everything being equivalent, the only real difference is that students need to find the time to watch the lectures on their own. However, students must be motivated to watch these lectures when they do not have a course schedule that requires them to be in a classroom at a set time every week. With that said, the withdrawal rates for both delivery formats were still quite low.

\section{Student Perceptions of Lecture Capture.}

An online student perceptions survey was provided to students in both sections near the end of each semester, although questions varied based on course delivery type. The main goal of the LC survey was to learn how students felt about various aspects of these courses and video streaming specifically, including overall satisfaction levels, viewing preferences, and perceptions of technological features. If students seriously disliked lecture capture, then using this delivery approach extensively would likely be problematic for both students and faculty over the long run, even if performance was acceptable.

The student perceptions survey for the LC group looked at a number of issues related to lecture capture, such as where and how often the videos were watched and quality of the technical aspects. Table 1 provides a summary of the pertinent survey results. Initially, students were asked to describe the primary location that they watched the video lectures. Eighty-five percent watched the lectures from their home, apartment, or dormitory room, and approximately seven percent watched from an on-campus location with Internet access.

The next question looked at students' video viewing habits. According to their responses, the majority $(51 \%)$ of the students in lecture capture courses appear to be keeping up with the course pacing and not waiting to watch the lectures. We were concerned that students may not be disciplined enough to keep pace. Only $15 \%$ said that they waited until near exam times to watch the videos.

Students typically only watched the video lectures once. This finding was somewhat surprising because we expected a higher percentage of students would watch the videos multiple times, which is one of the presumed benefits of this delivery format. More surprising, however, was that approximately $30 \%$ reported that they rarely or never watched the videos. There was no significant correlation between course grade and the number of times the videos were viewed.

Next, students were asked three questions related to the impact of lecture capture courses on their learning and motivation to learn. Seventy-two percent perceived that they had more control over their learning than they would in a traditional face-to-face class (39\% chose "definitely," while another $33 \%$ chose "probably"), most likely as a result of being able to watch the videos when and as often as they wished and because they could control the video playback. This finding 
agrees with several recent studies on the benefits of archived video capture (e.g., Cascaval et al., 2008; Nicholson \& Nicholson, 2010). Forty-three percent also responded that they felt LC enhanced their performance in the course, while only $28 \%$ thought that it did not. However, students did not feel that LC enhanced their interest in the course compared to a similar face-to-face course (38\% said yes and $41 \%$ said that it did not).

When asked to rate their LC experience, $80 \%$ indicated that it was as good as or better than in a traditional large lecture class. Sixty-two percent wrote that the flexibility and convenience of LC were what they liked the most about taking the course this way. Seventy-three percent also reported that they would choose to take another LC course. Students most likely to benefit from the flexibility and convenience of LC delivery are slightly older, employed, and/or having family responsibilities.

One question of particular interest to us was how often LC students chose to attend the live lecture, given that this option was available. Would high attendance in the live session invalidate the LC performance results? Of the 402 students who responded to this question, $72 \%$ said that they never attended a live session. Another 19\% reported that they attended a few times during the semester, and only $8 \%$ said they attended most or all of the live lectures. The $8 \%$ that attended most or all of the live lectures suggests that, given the class sizes, only about 25-30 students were consistently attending the 280 -seat classroom. The instructor confirmed that her classroom was rarely filled, other than during the first week of classes. Thus, the live session was a nice feature for a small number of students, but with the low attendance, we do not feel that the LC group was more like the face-to-face group; thus, we do not feel it is a cause for concern in interpreting the results.

\section{Instructor Ratings}

Finally, we were also curious about overall student ratings of the instructor in these two delivery modalities, since they were readily available to us. These ratings were obtained from the standard university course evaluations that are provided at the end of every course. They were obtained each semester for both course delivery formats. The course evaluation used a 5-point scale with categories of excellent, very good, good, fair, and poor. Averaged over both semesters, the overall course ratings of the instructor in the face-to-face sections were $90 \%$ positive (combined excellent, very good, and good ratings), with $27 \%$ being excellent ratings. In the LC sections, the instructor received $93 \%$ positive ratings, with $38 \%$ being excellent ratings. Thus, students in the LC sections gave the instructor slightly higher ratings than they did in the face-to-face sections, even with all readings, assignments, and exams being the same, and with very similar lectures provided. This result was somewhat surprising to us. As mentioned, students in the LC were older, more likely to be employed, and there were a higher percentage of females. We are not sure why the demographic differences would produce more favorable responses, but we plan to investigate this finding further. Possibly, students who liked the flexibility and convenience of LC carried these positive feelings over to the instructor?

\section{Conclusions}

This research was conducted to determine if the large scale use of instruction employing lecture capture resulted in comparable student performance, withdrawal rates, and student satisfaction relative to face-to-face instruction without lecture capture. The results were quite positive for the lecture capture courses in both student performance and perceptions and suggest that this course delivery modality may be a viable alternative to large section face-to-face instruction and a means to increase course access for students. 
Withdrawal rates were higher in the LC sections (5\%) compared to the face-to-face sections (2\%), which supports previous research. As such, the withdrawal results may reflect that lower level undergraduate students have more difficulty due to being on their own for the first time, needing to learn how to function successfully in college, having less experience with distance learning course formats, and so forth. Previous research on distance learning has shown that successful students typically are older, more independent, and more intrinsically motivated (e.g., Diaz, 2002; Moore \& Kearsley, 1996; Sitzmann et al., 2006).

Because we could not randomly select students to the two delivery conditions, we realize that this situation could have led to biases in the results. After all, it is conceivable that students who selfselected to take the lecture capture lessons would be more inclined to report positive things about their lecture capture experience. However, our demographic data (Table 2) suggest that the two groups were similar on many attributes, and with the large sample sizes and equivalent performance, we feel that this is not an appreciable problem.

Bell, Cockburn, McKenzie, and Vargo (2001) described the importance of flexible instructional delivery, including freeing students from having to be in a particular classroom at a set time. The implications of this flexibility mean that online instructional delivery with lecture capture can increase the potential student population for a particular course, program, or college. It would also increase the potential enrollment of employed students, those with family commitments, the disabled, and life-long learners. Gratton-Lavoie and Stanley (2009) also suggest that online course delivery opens up a competitive education market that may move beyond one geographic area of an intact university to include regional, national, and even international students. Thus, assuming that high quality instructional design is maintained, course size can be increased if technological advances such as automatic exam presentation and scoring, and/or graduate assistants are available for faculty support. Moskal, Caldwell, and Ellis (2009) describe a testing lab that works well for this purpose.

Concerning student perceptions, the majority of LC respondents preferred the added convenience and flexibility of being able to watch lectures whenever and wherever they wished. They also could review material when they missed a live lecture. Students taking courses enhanced with lecture capture systems have more opportunities to learn the material, which may explain positive performance differences that have been reported in some research on lecture capture.

There are several topics that warrant further investigation. It would be valuable to identify the number of video lectures that students actually access during their courses and how often they view them, which would allow one to accurately ascertain relationships between course grade and withdrawal results with video viewing frequency. This technological capability is now becoming more readily available and may provide significant research opportunities.

As technology continues to advance and fiscal constraints persist, especially in larger statefunded institutions, it is comforting to have evidence that student performance is not degraded by lecture capture delivery. It is no cliché that our students tend to be quite technology-savvy and are certainly not averse to registering for lecture capture courses. We believe this trend will continue into the future. Based on initial LC research, including the present study, it is reassuring to note that universities-are not short-changing students in response to the changing technology and fiscal limits that we face. Naturally, the preceding sentence is based on the caveat that instruction is well designed.

In conclusion, this research study generally supports the findings of both Moore and Kearsley (1996) and Clark (1983, 1994). Moore and Kearsley, in discussing distance learning as a whole, stated that "the weight of evidence that can be gathered from the literature points overwhelmingly to the conclusion that teaching and studying at a distance, especially that which uses interactive electronic telecommunications media, is effective when effectiveness is measured by the 
achievement of learning, by the attitudes of students, and by cost effectiveness" (p. 76). Clark (1983) noted that "the point is made, therefore, that all current reviews of media comparison studies suggest that we will not find learning differences that can be unambiguously attributed to any medium of instruction" (p. 457). More recently, Moskal, Dziuban, Upchurch, Hartman and Truman (2006) added that "the question is no longer whether online education is as good as face-toface instruction, but rather how to prepare and support faculty in the online environment and ensure that students achieve important learning outcomes whether they study in online or face-toface settings or both" (p. 26). Moskal et al. (2006) also posit that "with proper support mechanisms, online learning will grow at significant rates. Success and withdrawal rates will be more than acceptable and student satisfaction will be high." We believe that this applies to online learning using lecture capture as well.

\section{References}

Allen, M., Mabry, E., Mattrey, M., Bourhis, J., Titsworth, S., \& Burrell, N. (2004). Evaluating the effectiveness of distance learning: A comparison using meta-analysis. Journal of Communication. 54(30), 402-420.

Arbaugh, J.B., Godfrey, M. R., Johnson, M., Pollack, B. L., Niendorf, B., \& Wresch, W. (2009). Research in online and blended learning in the business disciplines: Key findings and possible future directions. Internet and Higher Education, 12, 71-87.

Bell, T., Cockburn, A., McKenzie, B., \& Vargo, J. (2001). Flexible delivery damaging to learning? Lessons from the Canterbury Digital Lectures project. In the $13^{\text {th }}$ Proceedings of the ED-MEDIA 2001 World Conference on Education Multimedia \& Telecoummunications, Tampere, Finland.

Cascaval, R. C., Fogler, K. A., Abrams, G. D., \& Durham, R. L. (2008). Evaluating the benefits of providing archived online lectures to in-class math students. Journal of Asychronous Learning Networks, 12(3-4), 61-70.

Clark, R. E. (1983). Reconsidering research on learning from media. Review of Educational Research, 53(4), 445-459.

Clark, R. E. (1994). Media will never influence learning. Educational Technology Research and Development, 42, 21-29.

Craig, J., Gregory, S., El Haggan, A., Braha, H., \& Brittan-Powell, C. (2009, November). Lecture capture systems: Are they worth it? Paper presented at the Educause Mid-Atlantic Regional Conference, Philadelphia, PA.

Dey, E. L., Burn, H. E., \& Gerdes, D. (2009). Bringing the classroom to the web: Effects of using new technologies to capture and deliver lectures. Research in Higher Education, 50, 377-393.

Diaz, D. P. (2002, May/June). Online drop rates revisited. The Technology Source. Retrieved October, 2011 from http://ts.mivu.org/default.asp?show=article\&id=981

Figlio, D., Rush, N., \& Yin, L. (2010). Is it live or is it Internet? Experimental estimates of the effects of online instruction on student learning. Cambridge MA: National Bureau of Economic Research

Gratton-Lavoie, C., \& Stanley, D. (2009). Teaching and learning principles of microeconomics online: An empirical assessment. Journal of Economic Education, 40(1), 3-25.

Kozma, R. B. (1994). A reply: Media and methods. Educational Technology Research and Development, 42, 11-14.

Lehman, J. D., \& Brickner (1996). Teachers' uses and perceptions of interactive videodiscs in the science classroom. The Journal of Computers in Mathematics and Science Teaching, 15, 85-102.

McFarland, D., \& Hamilton, D. (2005). Factors affecting student performance and satisfaction: Online vs. traditional course delivery. Journal of Computer Information Systems, 46(2), 25-33. 
McLaren, C. H. (2004). A comparison of student persistence and performance in online and classroom business statistics experiences. Decision Sciences Journal of Innovative Education, 2(1), 1-10.

Means, B., Toyama, Y, Murphy, R., Bakia, M., \& Jones, K. (2009). Evaluation of evidence-based practices in online learning: A meta-analysis and review of online learning studies. Center for Technology in Learning for the U.S. Department of Education, Office of Planning, Evaluation, and Policy Development Policy and Program Studies Service. Available at: www.ed.gov/about/offices/list/opepd/ppss/reports.html

Moore, M. G., \& Kearsley, G. (1996). Distance education: A systems view. Belmont, CA: Wadsworth Publishing Company.

Moskal, P., Caldwell, R., \& Ellis, T. (2009). Evolution of a computer-based testing laboratory. Innovate: Journal of Online Education, 5(6). Available at http://www.innovateonline.info/index.php?view=article\&id=672

Moskal, P. D., Dziuban, C., Upchurch, R., Hartman, J., \& Truman, B. (2006). Assessing online learning: What one university learned about student success, persistence, and satisfaction. peerReview, 8(4), 2629.

Navarro, P. (2000) Economics in the cyber classroom. Journal of Economic Perspectives, 14, 119-32.

Nicholson, J., \& Nicolson, D. B. (2010). A stream runs through IT: Using streaming video to teach information technology. Campus-Wide Information Systems, 27(1), 17-24.

Russell, T. (2006). No significant difference phenomenon. Accessed May 17, 2010 from http://www.nosignificantdifference.org

Sanders, D. W., \& Morrison-Shetlar, A. I. (2001). Student attitudes toward web-enhanced instruction in an introductory biology course. Journal of Research on Computing in Education, 33, 251-262.

Sitzmann, T., Kraiger, K., Stewart, D., \& Wisher, R. (2006). The comparative effectiveness of web-based and classroom instruction: A meta-analysis. Personnel Psychology, 59, 623-664.

Wise, M., \& Groom, F. M. (1996). The effects of enriching classroom learning with the systematic employment of multimedia. Education, 117, 61-69.

\section{Biographies}

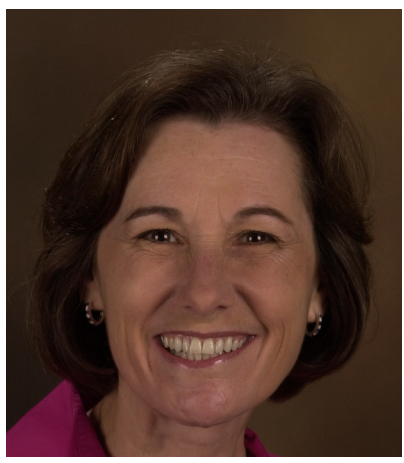

Patricia J. Euzent received her B.A. in Social Sciences at Coker College, Hartsville, SC. She received an M.A. in Economics at Clemson University, Clemson, SC. She is currently an Instructor of Economics at the University of Central Florida, Orlando, Florida. With more than 28 years of teaching experience, she has increasingly taken on the challenges of new technology and applied it in the classroom. Her main research interests are in the History of Economic Thought and Economic Education. 


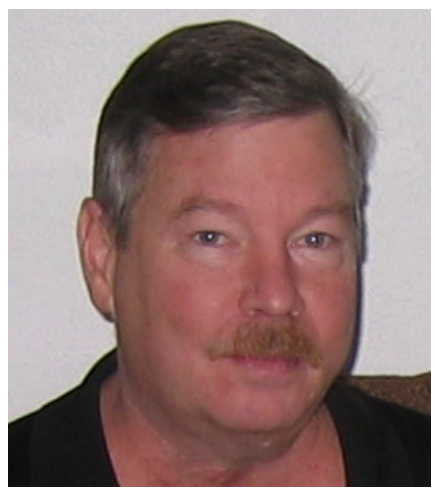

Thomas L. Martin received a B.S. degree in Mathematics and a B.A. degree in Economics in 1975 from Wake Forest University, Winston-Salem, North Carolina. He went on to earn a Ph.D. in Economics in 1981 from Rice University, Houston, Texas, specializing in International Economics. His teaching and research interests at the University of Central Florida are in the areas of International Economics, as well as Applied Microeconomics and The History of Economic Thought.

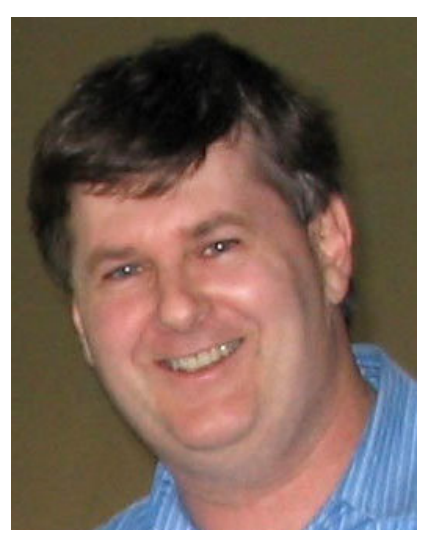

Patrick Moskal is the Director of Testing and Evaluation in the College of Business Administration (CBA) at the University of Central Florida. He has over 25 years of experience in the fields of education, training, and program evaluation, with the past 22 years at the University of Central Florida. He coordinates the collection and analysis of assessment data to improve CBA programs and maintain accreditation, as well as conducting research to support CBA initiatives. He received his Ph.D. in Psychology from the University of Notre Dame.

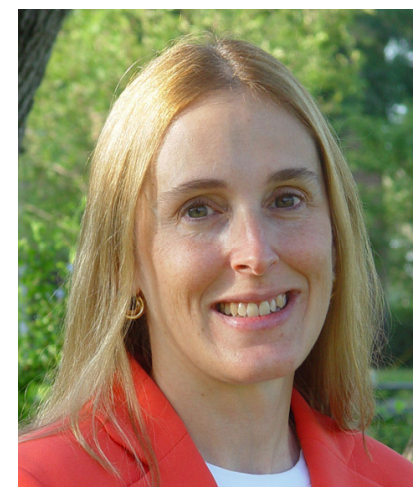

Patsy Moskal is the Associate Director for the Research Initiative for Teaching Effectiveness at the University of Central Florida (UCF), where she has been a faculty member since 1989. Since 1996, she has served as the liaison for faculty research of distributed learning and teaching effectiveness at UCF. She frequently serves as an evaluation consultant to school districts, industry, and government organizations. She received her BS and MS degrees in Computer Science, and her Ed.D. in Curriculum and Instruction from UCF. 